\title{
Chemical Flooding Enhanced Oil Recovery Using Local Alkali- Surfactant-Polymer
}

\author{
Uzoho C.U., Onyekonwu M., Akaranta O.
}

\begin{abstract}
Chemical flooding enhanced oil recovery is an aspect of enhanced oil recovery whereby chemicals (Alkaline, Surfactant and Polymer) are injected into the reservoir to release and produce trapped and mobile oil that remained in the reservoir after secondary flooding due to viscous, gravity and capillary forces. The success of this process has contributed immensely to nations energy need. One of the demerits of this type of enhanced oil recovery method is the high cost of the chemicals which makes the process worthwhile only when there is hike on oil price. As the Niger Deltaregion in Nigeria, West Africa prepares for tertiary recovery stage, it becomes important to introduce local contents as substitutes for the high cost chemicals for sustainability of the process. Research has shown that some local materials in Nigeria contain chemical compounds that can serve as Alkali, Surfactant and Polymer. Sand-pack Oil displacement flood tests were performed on 14 local materials using different concentrations under laboratory conditions. These local materials (potash, Elaeis guineensis, Musa sapientum, Khaya ivorensis, Nkankan (a native plant), Carica papaya's leaves, Cocos nucifera, kai-kai, Vernonia amygdalina, Abelmoschus esculentus, Brachystegia eurycoma, Detarium microcarpum, Irvingia gabonensis and Mucuna flagellipes) were screened for Chemflooding Enhanced Oil Recovery. The best performing local material Alkali, Surfactant, Polymer gave additional oil displacement efficiency of $17.3 \%, 5.2 \%$ and $18.7 \%$ respectively after conventional flooding. Blends of local materials Alkaline-Surfactant, Alkaline-Polymer, Surfactant-Polymer and Alkaline-Surfactant-Polymer were formulated with maximum oil displacement efficiency of 96.7\%, 93.5\%, 95.2\% and $90 \%$ respectively. The local materials Alkali and Polymer gave better results when used separately. These local materials were effective as Enhanced Oil Recovery agents and can as well substitute synthetic chemicals if refined and modified.
\end{abstract}

Index Terms- Alkali/Surfactant/Polymer Flooding,Chemical Flooding, Enhanced Oil Recovery, Local Materials.

\section{INTRODUCTION}

There are three stages of hydrocarbon production; namely primary, secondary, and tertiary (also known as Enhanced Oil Recovery). Enhanced Oil Recovery is mostly introduced when the secondary recovery method is no longer effective. There are different types of enhanced oil recovery method and chemical flooding is one of them; it entails the use of chemicals in form of alkali, surfactant and polymer to produce more oil beyond that recoverable by secondary recovery method (Mandal, 2015). This recovery method is

Uzoho C.U., African Centre of Excellence, Centre for Oilfield Chemicals Research, University of Port Harcourt, Port Harcourt, Rivers State, Nigeria. Onyekonwu M., Department of Petroleum and Gas, University of Port Harcourt, Rivers State, Nigeria

Akaranta O., Department of Chemistry, University of Port Harcourt, Rivers State, Nigeria. possible due to certain displacement mechanism like reduction in interfacial tension between oil and formation water, reduction in capillary pressure, emulsification of oil, wettability alteration of rock surface and mobility control (Laura, 2011). Mostly in oilfield operations, synthetic chemicals are used for Alkaline-Surfactant-Polymer flooding. In Nigeria, most of the Oilfield chemicals used for Oilfield operations are synthetic chemicals which are imported and expensive; with enormous logistics involved in getting them as at when needed. To discontinue this ugly trend (which impacts negatively on the nation's economy), research on local materials that can substitute these imported and expensive Oilfield chemicals should be taken seriously. In the University of Port Harcourt, Nigeria, Faculty of Engineering, Department of Petroleum and Gas Engineering; research interest on the use of local materials for Enhanced Oil Recovery is on-going. Moreso, in Nigeria, over $60 \%$ of its populous engages in agriculture and their standard of living still remains very low with the nation depending majorly on imported products; production of chemicals from these local materials will better the lives of farmers as more of them will be involved in the cultivation of these crops since research had shown that some of these local materials in Nigeria contain chemical components that can efficiently and effectively replace synthetic chemicals. Local materials like potash, Elaeis guineensis, Musa sapientum, Khaya ivorensis, Nkanka (a native plant), Carica papaya's leaves, Cocos nucifera, kai-kai, Vernonia amygdalina, Abelmoschus esculentus, Brachystegia eurycoma, Detarium microcarpum, Irvingia gabonensis and Mucuna flagellipes were used as local EOR agents in a sand-pack oil displacement test in the laboratory. By the results obtained most of them gave good recovery and can be used to replace synthetic chemicals if modified.

\section{LITERATURE REVIEW}

Alkali emulsify Crude oil and water, changes rock wettability from oil wet to water wet (Laura, 2011, Mojdeh, 2015). This reaction is dependent on overall acid count and varies with composition of Crude oil (Mojdeh, 2015). A Crude oil composition with low TAN cannot be considered for Alkaline flooding, generally below $20^{\circ} \mathrm{API}$ and in sandstone reservoirs temperature below $200^{\circ} \mathrm{F}$. The existence of acidic groups in crude oil is also supported by the total acid number $(0.38 \mathrm{mg} \mathrm{KOH} / \mathrm{g})$ of the crude oil. Mandal (2015) reports that $\mathrm{pH}$ value of 10 to 12 of alkaline is injected to improve recovery but Mojdeh (2015) reports that the $\mathrm{pH}$ above 9.5 is actually required for the alkali to undergo saponification process to produce the insitu-soap. 
Literature search shows that the ash of Elaeis guineensis and Musa sapientum contain sodium and potassium oxides in different percentage which when dissolved in water forms its hydroxide. These local alkalis are mostly used to produce soft soap by natives. Akanwu called Potash in Nigeria but commonly known as Trona (Sodium Sesquicarbonate, $\mathrm{Na}_{2} \mathrm{CO}_{3} \cdot \mathrm{NaHCO}_{3} .2 \mathrm{H}_{2} \mathrm{O}$ ) is an alkaline salt. It is a naturally occurring mineral used as spice, soup thickening and a tenderizer for meat and fish. Impurities in Potash are sand, clay; including metals like magnesium, titanium, iron, calcium, silicon and aluminum. Gail, 2013 reported the presence of lead in potash as ranging from 1 to $18 \mathrm{ppm}$. This is indeed significant.

The main objectives of surfactant flooding are wettability alteration from oil-wet to neutral to water-wet and reduction in interfacial tension between the formation water and Crude oil (Mohammad et. al., 2018, Mohammad et. al., 2014). One of the demeritsof this process is its adsorption to rock surfaces which decreases at high flowrate (Mohammad et al., 2018). The high cost and amount of adsorption to rock surfaces affects the robustness of surfactant flooding (Mohammad et.al., 2014).

In the attempt to reduce this high cost of synthetic surfactant and reduce its adsorption on rock surfaces; local materials possessing emulsifying and surface active properties are been researched on.

Cocos nucifera's yeast has been reported to possess emulsifying properties. An experiment was conducted extracting mannoprotein from the cell walls of Saccharomyces cerevisiae KAOI which was cultivated in YM medium autoclaved in a pH 7.0 citrate buffers in 60minutes, resulting in a mannoprotein yield of $0.32 \mathrm{~g} / \mathrm{g}$ wet cells. The extracted mannoprotein was evaluated to find out its physical and chemical stability, which ascertains its possible use in processed foods as natural emulsifier (Paweena et al., 2010). The mannoprotein extracted from this experiment had emulsifying properties similar to that of lecithin and gum Arabic usually used as emulsifiers in food industries. Soybeans oil contains high percentage of lecithin. Lecithin is a mixture of triglycerides. It consists of low and high saturated fat in varying percentage (Qingyi et al., 2011). Soybeans oil is also commonly used as a raw material or fermentation substrate in surfactant production. Modification of soybeans is a new area of interest and it is achieved by converting its double bonds to more reactive bonds througha method called Epoxidation.By this method, more reactive oxirane ring groups or epoxides are formed by reacting with proxides or peracids.Literature search had shown that Carica papaya leaves contain saponins and its surface active properties are used for its characterization. For example, it foams in water and used in ancient time as soap. Hence, their derived name sapo, saponis meaning soap in Latin. They also form micelles with lipids due to their detergent properties (Chaieb, 2010).

Viscosity of a displacing fluid like water is improved whenpolymer is added which minimizes channeling and provides a mobility ratio that is favourable $(M R>1)$. These polymers improve sweep efficiency volumetrically (Abubakar, 2015); which makes them applicable for mobility control in EOR noting that to change the Crude oil properties or the permeability of the reservoir is almost impossible economically and practically. This mobility control method focuses on altering the compositional properties of the fluid injected into the reservoir. Its main purpose is to ensure that the ratio of the displaced and displacing fluid is changed to a favourable number allowingthe injected fluid not to bypass the displaced fluid (Shunhua, 2008).

Food thickeners contain elements like Potassium, Calcium, Manganese, Iron, Nickel, Copper, Zinc and Sodium (Onudibia et al., 2014). Research on food thickeners shows their chemical composition and nutritional value. These food thickeners or thickening agents are ingredients that increase the viscosity of aqueous solution. They improve suspension, increase stability and provide body to the added materials. Due to their thickening ability, these nutritional seeds are used in soup as thickeners. They also possess other industrial applications that might lead to food scarcity; thereby attracting investment in its cultivation as a result of increased value.Ikechukwu et al., 2010 analyzed Brachystogia nigeria, Deutarium microcarpum, Afzelia africana and Mucuna sloanei, and found out that they contain essential amino-acids and other important chemical components. These local seed shells were removed, dried and pulverized. The results showed that, the protein content of Brachystogia nigeria (\%wt) $(0.45 \pm 0.01)$ were greater than that of Deutarium

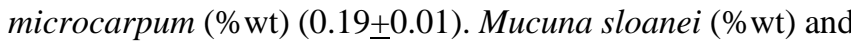
Afzelia africana (\%wt) were $(0.52 \pm 0.05)$ and $(6.29 \pm 0.10)$ respectively. The moisture content for Brachystogia nigeria, Deutarium microcarpum, Mucuna sloanei and Afzelia africana were $4.30 \%, 5.80 \%, 4.07 \%, 2.80 \%$ respectively. This moisture content result shows that they contain moderately low moisture content which could inhibit the breaking down of the fatty materials by microbial and hydrolysis attack.These highly saturated oils are of great importance as food, lubricants and in soap industry. Their industrial value is a function of its specified fatty acids and the tendency of being combined or modified by other chemicals (Ikechukwu et al., 2010). Another research on Mucuna flagellipes, Brachystegia eurycoma and Detarium microcarpum showed the presence of major and trace elements in these food thickeners. Potassium and calcium were present as major elements while Manganese, Iron, Nickel, Copper and Zinc were present as trace elements. No toxic element was found in them using Energy Dispersive $\mathrm{X}$-Ray Fluorescence (EDXRF).

Nwosu et al., 2012 reports that boiling increases the emulsification values of Brachystegia eurycoma, Detarium microcarpum and Mucuna flagellipes. These thickeners swell when mixed with water. Swelling which means the ability to increase in volume is attributed to both protein (at low temperature) and starch mixing with water (at high temperature). The swelling index of raw Brachystegia eurycoma, Detarium microcarpum and Mucuna flagellipes were recorded as $1.34 \%, 2.92 \%$ and $2.08 \%$ respectively. This they concluded that Detarium microcarpum, because of its high swelling index could be used for preparing soup in large quantity while Brachystegia eurycoma should be used for small quantity soup since its swelling index is low. This result 
also implies that Detarium microcarpum might not be a good choice for polymer flooding Chemical EOR as it could plug the pore spaces because of its high swelling index in water.

Abelmoschus esculentus ranked first before other vegetable crops. It is a source of calorie $(4550 \mathrm{kcal} / \mathrm{kg})$ for human consumption. In Brazil, West Africa, India and the United States; Abelmoschus esculentus is a major vegetable mostly consumed by its populace. In Nigeria, it is one of the most important vegetables in terms of consumption and production area. Abelmoschus esculentusin Nigeria alone occupies about 1.5 million hectares of the arable land. This vegetable is highly nutritious in potassium, vitamins, calcium, and other mineral matters. Abelmoschus esculentus mucilage is appropriate for medicinal and industrial applications (Onunkun, 2012). Industrially, Abelmoschus esculentus mucilage is commonly used to glace certain papers and also useful in confectionary amidst others. Research shows that Abelmoschus esculentus contains saponin, saponaretin and vitexin (Thomas-Amazon.com). The work of Adetuyi et al., 2011 on nutrient, antinutrient, mineral and Zinc bioavailability of Abelmoschus esculentus showed that Abelmoschus esculentus saponin content ranges from $0.470-$ $0.612 \%$ while oxalate ranges from $0.324-0.506 \%$. Another work from Mee Calu et al., 2015 reports the absence of saponin on Abelmoschus esculentus leaves.

In this research, 14 local materials (potash, Elaeis guineensis, Musa sapientum, Khaya ivorensis, Nkankan (a native plant), Carica papaya's leaves, Cocos nucifera, kai-kai, Vernonia amygdalina, Abelmoschus esculentus, Brachystegia eurycoma, Detarium microcarpum, Irvingia gabonensis and Mucuna flagellipes) were used as local EOR agent in a Sand-pack oil displacement flood test under laboratory conditions. The ash of Elaeis guineensis, Musa sapientum, Khaya ivorensis and potash were used as local alkali. Vernonia amygdalina extract, Nkankan, Carica papaya leaves extract, local gin (kai-kai) and Cocos nucifera were also used as local source of surfactant while Irvingia gabonensis, Brachystegia eurycoma, Abelmoschus esculentus, Detarium microcarpum and Mucuna flagellipes were the local polymer used in this experiment. The best among the local alkali, local surfactant and local polymer were used to formulate blends of local Alkaline-Surfactant, local Alkaline-Polymer, local Surfactant-Polymer and local Alkaline-Surfactant-Polymer. The results were compared and conclusion drawn based on experimental results in agreement with literature search.

\section{MATERIALS AND METHOD}

The Crude oil used for this research was obtained from a field in Nigeria, supplied by Laser Engineering and Resources Consultants Limited, Port Harcourt, Rivers-State, Nigeria. It has a viscosity of $38 \mathrm{cP}$, TAN $0.226 \mathrm{mg} \mathrm{KOH} / \mathrm{g}$, ${ }^{\circ}$ API of $22.35 @ 28^{\circ} \mathrm{C}$ and density $0.9197 \mathrm{~g} / \mathrm{cm}^{3}$. It can be classified as medium crude. Sand-packs were prepared using sand grains size between 53 to 210 microns. The Sand-packs were saturated with brine and its porosity calculated using Saturation method. The Sand-pack oil displacement flood tests were conducted to know the effectiveness of the local materials extracts used as EOR agents. Table 1 shows the properties of the Test fluids used for this experiment.

\section{EXPERIMENTAL DESCRIPTION}

Apparatus: Unconsolidated Sand-packs, Core-holder, Rubber boot, End-stems, Positive displacement pump, Pipes/values/fittings, Measuring cylinders, Beakers, Conical flasks, Canon viscometer, Digital Vernier caliper, Density bottle, Spatula, pH meter, Filter papers, Funnels, Water bath, Spanners, Stop watch, Tripod stand, Fluid containers, Industrial sieve, and Stirrer.

Materials: Crude Oil, Brine, Industrial salt, two species of Irvingiagabonensis, Abelmoschus esculentus, Brachystegiaeurycoma, Mucunaflagellipes, Detariummicrocarpum, Potash, Musa sapientum, Khayaivorensis, Elaeisguineensis, Nkankan (a native plant in Eastern Nigeria), Carica papaya leaves, Vernoniaamygdalina, Cocosnucifera and Local gin (kai-kai).

Brine: Brine was prepared using an industrial salt $(\mathrm{NaCl}-$ $99.9 \%$ pure with MW 58.44). It was dissolved in water and properly stirred using a stirrer. Its concentration was $3 \%$ $(30,000 \mathrm{ppm}$ or $30 \mathrm{~g} / \mathrm{l})$ considered as moderate salinity for sea water. Brine density was $1.02 \mathrm{~g} / \mathrm{cm}^{3}$.

Design: The sand-pack oil displacement flood test (Fig. 1) was performed with different concentrations; $1 \& 2 \%, 0.1,1$ $\& 2 \%, 0.1 \& 0.5 \%$ for Alkaline, Surfactant and Polymer respectively (As recommended by Shell ENORDET and Abhijit, 2012), though local alkali concentration was increased - potash (3 to 5\%) and local polymer Abelmoschus esculentus (1 to $2 \%$ ). This was done to form an effective local ASP blend.

The average sand-pack length and diameter is $7 \mathrm{~cm}$ and $4 \mathrm{~cm}$ respectively; the $\mathrm{pH}$, density and viscosity for each sample were determined. Medium crude oil type was considered for this experiment with respect to the Niger Delta region, Nigeria, West Africa.

The best performing Alkali, Surfactant and Polymer EOR agent was used to formulate blends of local Alkaline-Surfactant (AS), Alkaline-Polymer (AP), Surfactant-Polymer (SP) and Alkaline-Surfactant-Polymer (ASP). Sand-pack oil displacement flood test was carried out using these different blends and the best blend determined. The best local materials were experimented at a pressure of 1000 - 3000psi.

The EOR agents were dried and pulverized before been dissolved in water (the weight of EOR agent measured with a known measurement of water to give the required concentration).

Mineral Oil: Crude Oil with viscosity $38 \mathrm{cP},{ }^{\circ} \mathrm{API}$ of 22.35 and Specific gravity at $28^{\circ} \mathrm{C}$ of $0.9197 \mathrm{~g} / \mathrm{cm}^{3}$ was used for this experiment.

Local Alkali: Potash, Elaeisguineensis, Khayaivorensis, Musa sapientum

Local Surfactant: Local gin (kai-kai), Cocosnucifera, Vernoniaamygdalina, Carica papaya leaves and Nkankan (a native plant in Eastern Nigeria, West Africa)

Local Polymer: Irvingiagabonensis, Abelmoschus esculentus, Brachystegiaeurycoma, Detariummicrocarpum, and Mucunaflagellipes 


\section{A. Process Description}

i. Unconsolidated Sand-packs were prepared and saturated with Laboratory Brine (30,000ppm, $3 \%$ or $30 \mathrm{~g} / \mathrm{l})$.

ii. Pore volume, bulk volume and porosity measured using Saturation method.

iii. The saturated sand-packs were used foroil displacement flood test in a horizontal position.

iv. The positive displacement pump was used to pump the fluid through the inlet pipe into the core-holder.

$v$. The flooding experiment began with a desaturation process using Crude oil as the displacing fluid.This displaces theLaboratory brine in the Sand-pack until irreducible water saturation at a fixed rate; until no sight of water through the outlet pipe into the measuring cylinder. The oil breakthrough time was recorded.

vi. A control experiment was carried out injecting $14 \mathrm{PV}$ of Laboratory Brine.

vii. Other experiments were performed following same procedure above but water flooding until 10PV Laboratory Brinehas been injected. The time forwater breakthrough was taken as the time the first drop of water was sighted through the outlet pipe. Therecovered oil and laboratory brine produced were recorded.

viii. 2 PV EOR extract was also injected to flood until zerooil could be recovered at the residual oil saturation. Recovered oil and producedEOR extract were recorded.

ix. After which, the unconsolidated sand-pack was removed from the core-holder and weighted.

$\mathrm{x}$. Thisprocess was repeated for each EOR extract used.

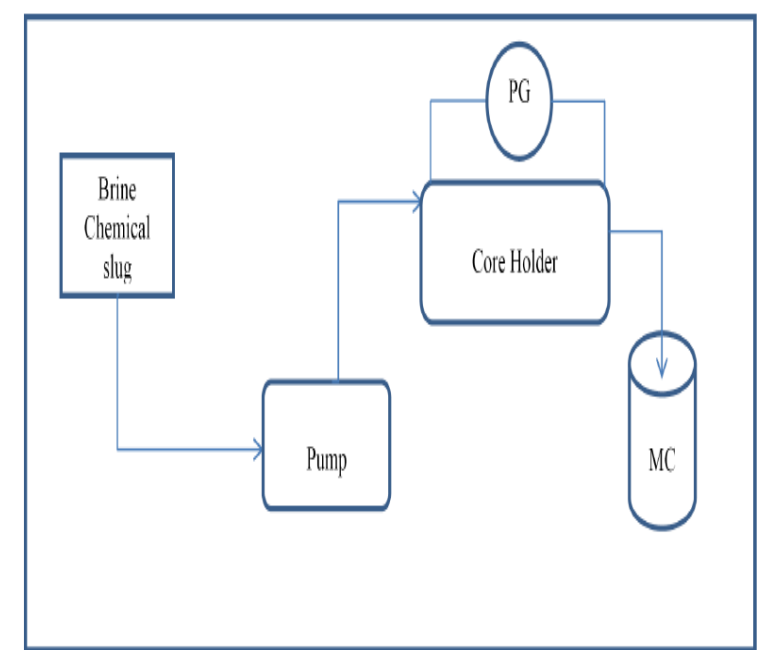

Figure 1-Schematic Diagram of Experimental Set-up

\section{RESULTS AND DISCUSSION}

All the local material alkali, surfactant and polymer were subjected to same conditions and the best among them were selected based on a selection criterion which was basically on cost of local material, value and availability in order of importance. Table 1 shows the properties of the test fluids, which verified the effect of $\mathrm{pH}$ on the alkali performance.

Table 1: PROPERTIES OF TEST FLUIDS

\begin{tabular}{llll} 
Sample & $\mathbf{p H}$ & $\begin{array}{l}\text { Density } \\
\left(\mathbf{g} / \mathbf{c m}^{\mathbf{3}}\right)\end{array}$ & $\begin{array}{l}\text { Dynamic Viscosity } \\
(\mathbf{c P})\end{array}$ \\
\hline $\mathrm{PE} \mathrm{g}$ & 11.9 & 1.0420 & 0.9563 \\
$\mathrm{UE} \mathrm{g}$ & 11.7 & 1.0320 & 0.9174 \\
$\mathrm{M} \mathrm{s}$ & 11.1 & 1.0300 & 0.9291 \\
$\mathrm{~K} \mathrm{i}$ & 9.5 & 1.0078 & 0.9616 \\
$\mathrm{C} \mathrm{n}$ & 4.1 & 1.0216 & 1.6669 \\
$\mathrm{~V} \mathrm{a}$ & 5.4 & 1.0212 & 1.1061 \\
$\mathrm{C} \mathrm{p} \mathrm{LE}$ & 9.8 & 1.0340 & 1.0352 \\
$0.1 \% \mathrm{~A} \mathrm{e}$ & 7.4 & 1.0220 & 0.9897 \\
$0.5 \% \mathrm{~A} \mathrm{e}$ & 6.9 & 1.0240 & 1.0592 \\
$0.1 \% \mathrm{~B} \mathrm{e}$ & 4.4 & 1.0280 & 0.9577 \\
$0.5 \% \mathrm{~B} \mathrm{e}$ & 3.3 & 1.0260 & 1.0493 \\
$0.1 \% \mathrm{M} \mathrm{f}$ & 4.8 & 1.0260 & 0.9693 \\
$0.5 \% \mathrm{M} \mathrm{f}$ & 4.1 & 1.0280 & 1.0824 \\
$0.1 \% \mathrm{D} \mathrm{m}$ & 4.8 & 1.0260 & 1.0310 \\
$0.5 \% \mathrm{D} \mathrm{m}$ & 4.2 & 1.0260 & 1.0179 \\
$0.1 \% \mathrm{I} \mathrm{gU}$ & 4.6 & 1.0300 & 0.9397 \\
$0.5 \% \mathrm{I} \mathrm{gU}$ & 5.0 & 1.0280 & 0.9760
\end{tabular}




$\begin{array}{llll}0.1 \% \text { I gM } & 4.6 & 1.0140 & 0.9173 \\ 0.5 \% \text { I gM } & 4.8 & 1.0120 & 4.0683 \\ 1 \% \text { Potash } & 11.9 & 1.0400 & 1.5662 \\ 2 \% \text { Potash } & 12.2 & 1.0380 & 1.0547 \\ \text { Nkankan } & 4.5 & 1.0380 & 2.1694 \\ \text { Local gin } & 3.7 & 0.9505 & 2.2529 \\ \text { Brine } & 6.9 & 1.0240 & 1.0104 \\ \text { Crude } & \mathrm{NA} & 0.9197 & 38.0003\end{array}$

In Table 2, the reduction in the TAN of the crude oil from $0.226 \mathrm{mgKOH} / \mathrm{g}$ to $0.0887 \mathrm{mgKOH} / \mathrm{g}$ in the presence of an alkali (potash) confirms the saponification process that takes place between the alkali and naphthenic acids in crude oil forming an insitu-soap which results in the reduction of interfacial tension between crude oil and formation water.

Abelmoschus esculentusshould also beconsidered as an effective polymer for enhanced oil recovery as it shows insignificant change in the ${ }^{\circ}$ API of the crude oil (see Table 2).

Table 2: Effect of local materials on Crude Oil properties

\begin{tabular}{|c|c|}
\hline \multicolumn{2}{|l|}{ Result of the Crude Oil Analysis } \\
\hline Crude Oil Sample Properties & $\begin{array}{l}\text { Analytical } \\
\text { Method }\end{array}$ \\
\hline API Gravity@60 $60^{\circ} \mathrm{F}\left[{ }^{\circ} \mathrm{API}\right]$ & ASTM D 5002 \\
\hline $\begin{array}{l}\text { Kinematic Viscosity at } 50^{\circ} \mathrm{C} \\
\text { [cST] }\end{array}$ & $\begin{array}{l}\text { ASTM } \\
7042-04\end{array}$ \\
\hline $\begin{array}{l}\text { Kinematic Viscosity at } 60^{\circ} \mathrm{C} \\
\text { [cST] }\end{array}$ & $\begin{array}{l}\text { ASTM } \\
7042-04\end{array}$ \\
\hline $\begin{array}{l}\text { Kinematic Viscosity at } 70^{\circ} \mathrm{C} \\
{[\mathrm{cST}]}\end{array}$ & $\begin{array}{l}\text { ASTM } \\
7042-04\end{array}$ \\
\hline 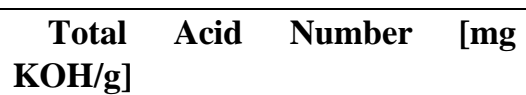 & $\begin{array}{r}\text { ASTM } \\
0974-04\end{array}$ \\
\hline $\begin{array}{l}\text { A. LOCAL ALKALI } \\
\text { Among the local alkalis used for th } \\
2 \% \text { performed best (Fig. 2). During } \\
\text { formed an emulsion, verifying that on } \\
\text { alkaline flooding is emulsification. I } \\
\text { anhydrous potash gave a better resul } \\
\text { the displacement efficiency increasec } \\
\text { as the pH increased, the maximum } \\
\text { also increased which showed the e } \\
\text { solution on oil displacement during al }\end{array}$ & $\begin{array}{l}\text { s experiment,potash @ } \\
\text { the flood test, potash } \\
\text { of the mechanisms for } \\
\text { was also observed that } \\
\text { than hydrouspotash as } \\
\text { It is worth noting that } \\
\text { lisplacement efficiency } \\
\text { fect of pH of alkaline } \\
\text { kaline flooding (Fig. 3). }\end{array}$ \\
\hline
\end{tabular}

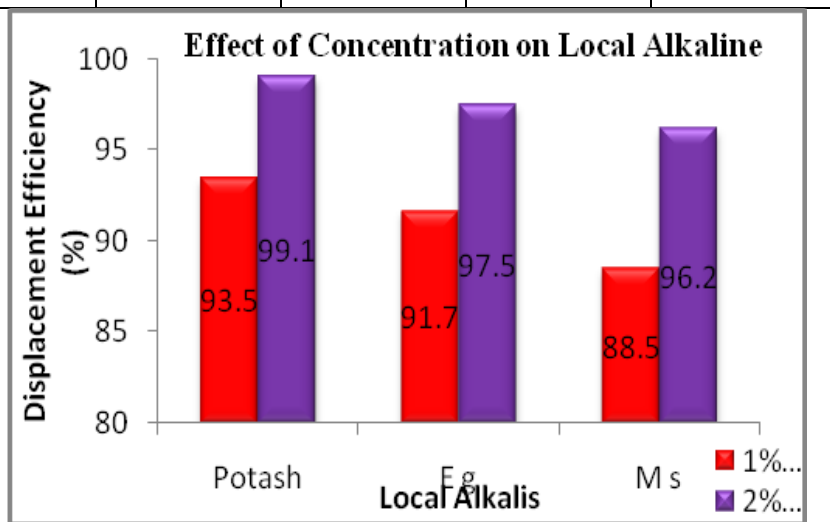

Fig. 2: Alkaline flooding at two different concentrations

Elaeis guineensis was purified using a local leafwhich made its filtration easier when compared to that of the unpurified Elaeis guineensis. But the result from its oil displacement efficiency showed that the purification process was not necessary, as the oil displacement efficiency for both purified 
and unpurified Elaeis guineensis was same. Literature says (Mojdeh, 2015) for an alkali to undergo saponification process to produce insitu soap; its $\mathrm{pH}$ must not be less than 9.5. This could be the result why the Khaya ivorensis did not perform as good as others because its $\mathrm{pH}$ is below 9.5.

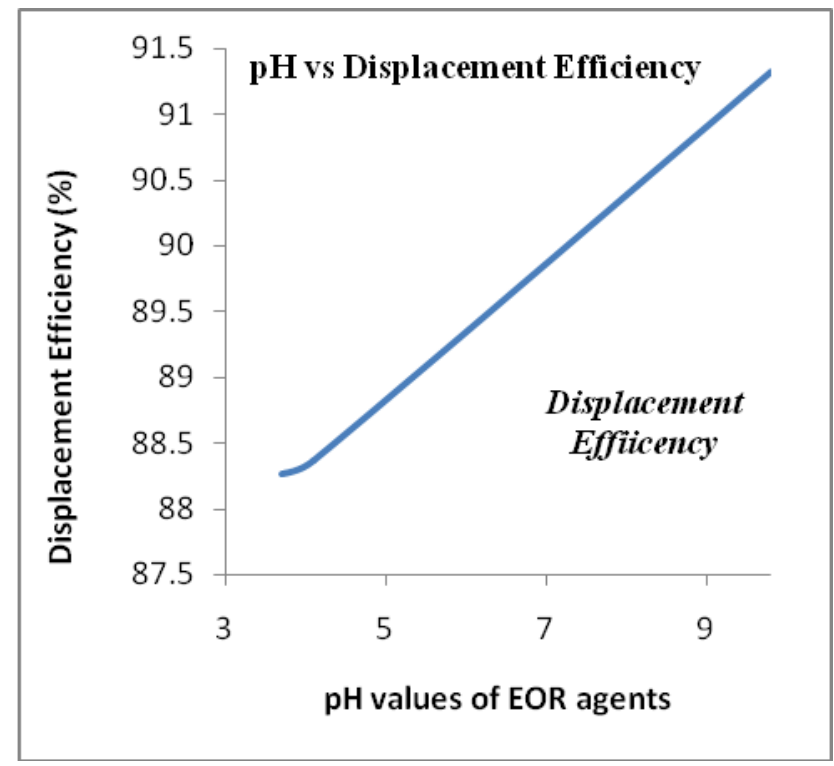

Fig. 3: A graph showing the effect of pH on displacement efficiency

The performance of potash (a local alkali) was observed to be constant beyond $2 \%$ concentration (Fig. 4).

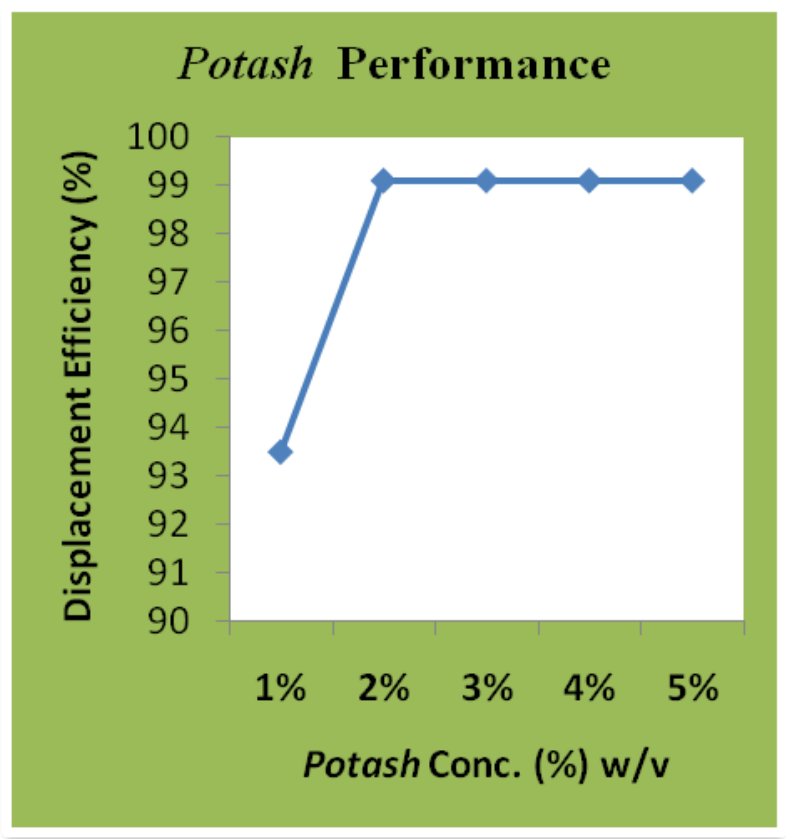

Fig. 4: Performance of Potash @ various concentrations

\section{B. LOCAL SURFACTANT}

The presence of yeast in fresh Cocos nucifera made it perform better than local gin (kai-kai). Literature (Paweenaet al., 2010) has it that yeast contains mannoprotein that exhibits surface active characteristics at the interface of two immiscible fluids. This could be the reason why the Cocos nucifera used for this experiment performed better than the local gin (kai-kai) whose yeast had completely died off as a result of increased alcohol content; though its difference was marginal. The problem with the use of Cocos nucifera is that during the flood test, it was noted that the Cocosnuciferacame out as effluent before recovering the crude. This shows that the Cocos nucifera (co-surfactant) takes much time to displace the trapped oil from the rock surface.

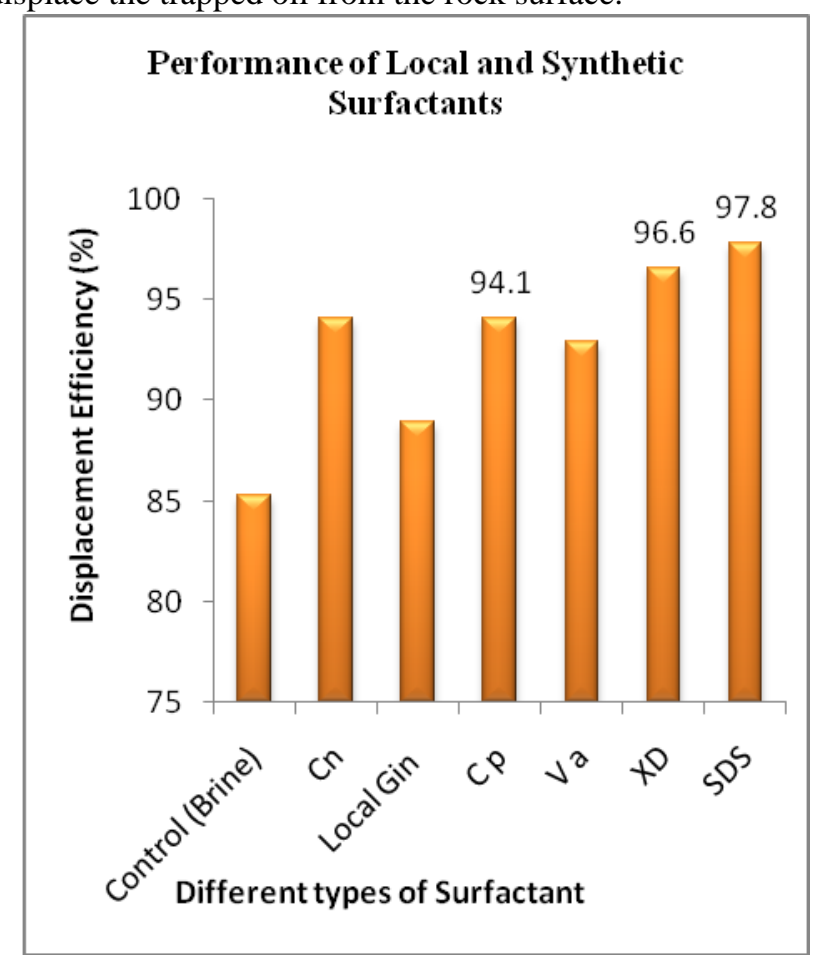

Fig. 5: Displacement Efficiency for the different local and synthetic surfactant

Vernoniaamygdalinacontains potassium richlyand forms its hydroxide when dissolved in water; it was selected for use as local surfactant for Chemical Flood EOR because of its foaming effect. The result was poorwhen compared to that of others. It formed a brownish yellow colouration as it reacted with the crude during the flood test. Literature search shows that Carica papaya leaves contain saponin (Chaieb, 2010) and decades ago, it was used for washing and bathing. Even now, most soap contains Carica papaya leaves extract as one of its component. Saponin is a natural surfactant, which is used for cream and soap in recent times. Fresh Carica papaya leaves were soaked in water and its extract used as an EOR agent. Its result was best for the local surfactants experimented with (Fig. 5). Nkankan, a native plant found in the South-East part of Nigeria was selected because of its high viscosity in hot water, though its recovery was poorwith a $\mathrm{pH}$ of 4.5 .

\section{LOCAL POLYMER}

Food thickeners like Irvingia gabonensis, Brachystegia eurycoma, Detarium microcarpum, Mucuna flagellipes and Abelmoschus esculentus were used as local polymers. These local polymers were dried, milled, subjected to same condition. Two different concentrations $(0.1 \%$ and $0.5 \%)$ were used for the flooding test as recommended in literature (SHELL ENORDET). It was observed that as the 
concentration increased from $0.1 \%$ to $0.5 \%$, some of these local polymers ceased flow (Fig. 6). Irvingia gabonensis could not flow at a higher concentration of $0.5 \%$ as its aggregate size plugged pore spaces. Even its viscosity at this concentration could not be determined using the canon viscometer at room temperature. Brachystegia eurycoma, Detarium microcarpum and Mucuna flagellipes foaming capacity as given in literature is $2.30 \%, 1.80 \%$ and $3.40 \%$ respectively. The swelling index of $1.34 \%, 2.92 \%$ and $2.08 \%$ was given for raw Brachystegiaeurycoma, Detariummicrocarpum and Mucunaflagellipes respectively (Nwosuet. al., 2012). This verifies why Brachystegia eurycoma and Mucuna flagellipes gave better oil recovery than Detarium microcarpum. Detarium microcarpum is more hygroscopic than others with a moisture content of $5.80 \%$ (Ikechukwu et. al., 2010). So Detarium microcarpum is not recommended as a local polymer for chemical EOR. It was also observed during the sandpackoil displacement flood test with these local polymers that their $\mathrm{pH}$ reduced with increase in concentration. Abelmoschus esculentus was very effective; its mobility control was best compared to other local polymers. It was observed that Abelmoschus esculentus at higher concentration had a washing effect instead of its normal sweep mechanism. This is becauseAbelmoschus esculentus contain saponin (Adetuyiet.al., 2011) but its saponin (surface active property) content was more effective at higher concentration.

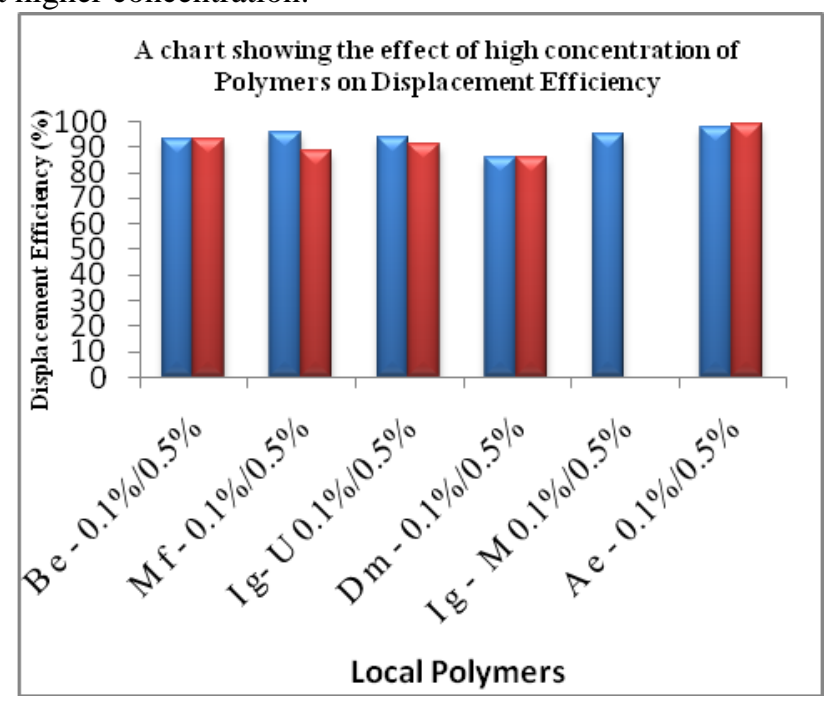

Fig. 6: Displacement efficiency of local polymers at different concentrations.

Polymer concentration and its viscosity are major factors that affect their performance during flooding. Figure 7 shows a decline in Abelmoschus esculentus performance at higher concentration beyond $1 \%$.

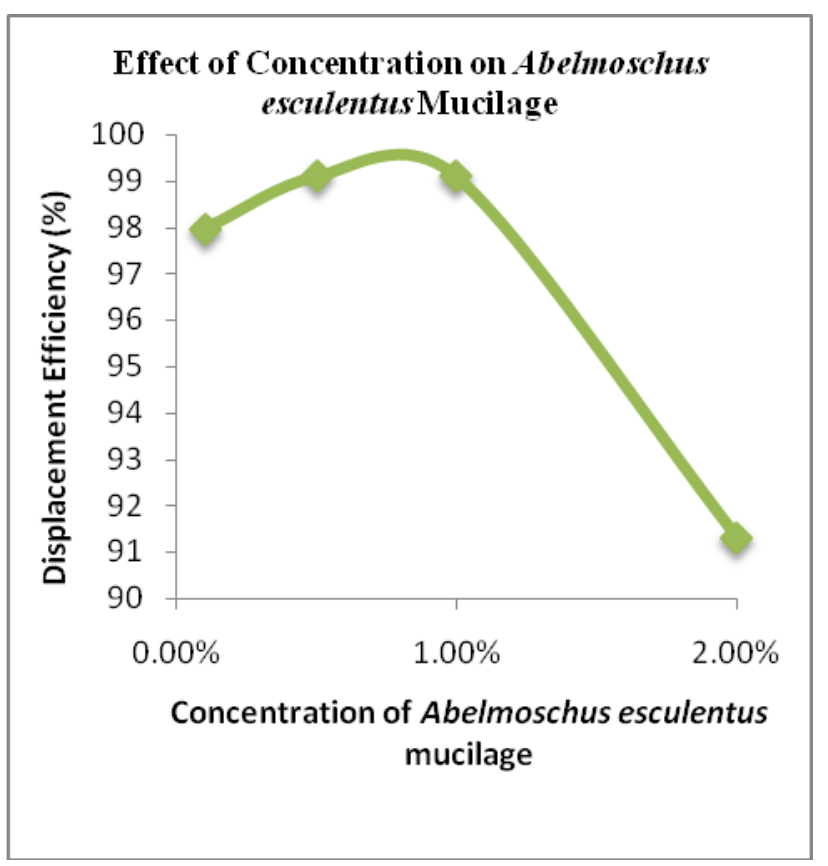

Fig. 7: Performance of Abelmoschus esculentus @ various concentrations.

\section{BLENDS OF ALKALI/SURFACTANT/POLYMER}

LOCAL

The best performing local alkali, surfactant and polymer were selected as potash, Carica papaya leaves extract and Abelmoschus esculentus respectively. Different blends were formulated from the local materials best performing alkali, surfactant and polymer to ascertain the best blend for Niger Delta, Nigeria reservoir crude. This formulation was done using their optimum concentration. AS was formulated using potash/Carica papaya leaves extract, AP with potash/Abelmoschus esculentus, SP with Carica papaya leaves extract/ Abelmoschus esculentus and ASP with potash/Carica papaya leaves extract/ Abelmoschus esculentus. Fig. 8 shows their result. From the result, it can be seen that the local material EOR agents performed better when used singly than when used as a blend.

The AS blend gave a better result among the four different blends formulated. This could be as a result of an ultra-low IFT level achieved between the oil and formation water as a result of insitu crude-soap formed by the potash and the organic acid component of the crude (Table 2) which was balanced by the injected natural surfactant (saponin) from Carica papaya leaves extract. The AP result was not as good as that of AS since itwas reported that AS Flooding is best at room temperature.

Literature shows that ASP blends are more effective for Crude oil with high viscosity. ${ }^{\circ} \mathrm{API}<19$, Oil saturation $>45$ and viscosity $<35 \mathrm{cP}$ are conditions for a good ASP flood. Viscosity $<35 \mathrm{cP}$ is best for Alkaline and Surfactant flooding, ${ }^{\circ} \mathrm{API}$ of 29 is best for Alkaline flooding, $10 \mathrm{cP}<$ Oil viscosity $<150 \mathrm{cP},{ }^{\circ} \mathrm{API}>15$ and Oil saturation $>30 \%$ is good for Polymer flooding and AS Flooding is best at $27^{\circ} \mathrm{C}$.

From the literature search above, the result from this research can be explained and confirmed. From the experiment, AS blend performed better than others at room temperature (Fig. 8). The ASP blend did not perform best as 
expected, since the viscosity of the crude $(38 \mathrm{cP})$ used was above $35 \mathrm{cP}$ and its ${ }^{\circ} \mathrm{API}>19$. This could also explain why the local polymer (Abelmoschus esculentus) performed best among all other forms of Chemical Flooding EOR used, since polymer flooding is a good candidate for Crude oil with viscosity $>35 \mathrm{cP},{ }^{\circ} \mathrm{API}>15$ and Oil saturation $>30 \%$.

The result from the analysis in Table 2 showed that the initial Crude Oil TAN was $0.226 \mathrm{mg} \mathrm{KOH} / \mathrm{g}$ but when mixed with potash; the TAN reduced drastically to $0.0887 \mathrm{mg}$ $\mathrm{KOH} / \mathrm{g}$ indicating that the local alkali (potash) actually reacted with the acidic component of the crude oil to form an insitu-soap. The Crude Oil blend with Abelmoschus esculentus showed no significant change in the ${ }^{\circ}$ API of the Crude Oil.

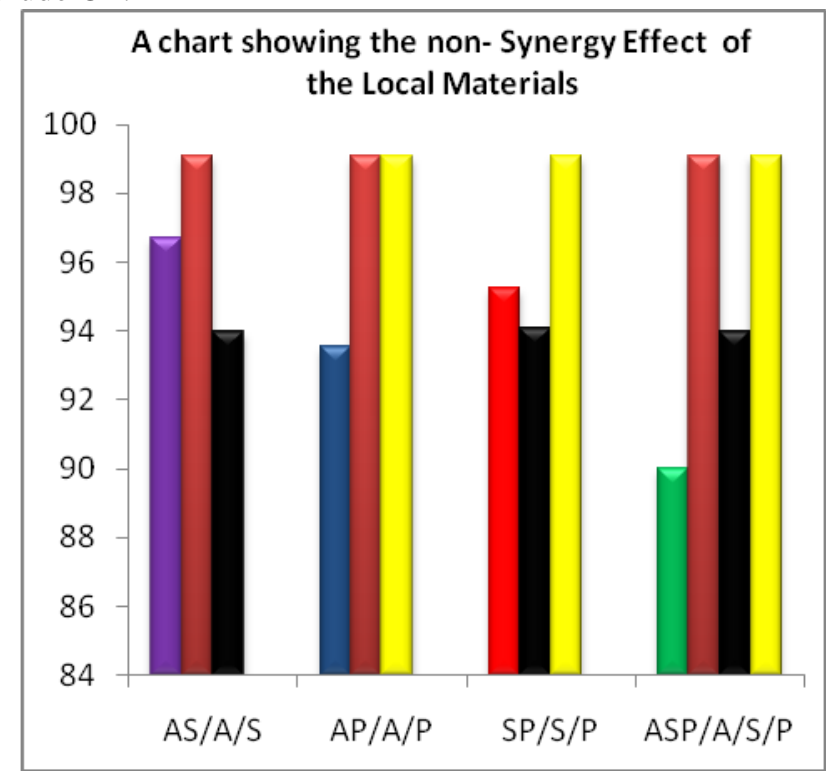

Fig. 8: Graph comparing the effectiveness of the blends to the single use of the local material

\section{CONCLUSION}

Chemical Flood Enhanced Oil Recovery is a function of crude oil type, fluid properties and reservoir conditions. Its preferential method (whether Alkaline, Surfactant, Polymer or its various blends) depends on these functions. The best performing local alkali, surfactant and polymer were potash, Carica papaya leaves extract and Abelmoschus esculentus respectively. The best blend for the Crude oil type used for this research was AS flooding with potash/Carica papaya leaves extract since the experiment was done at room temperature.

The best EOR agents among the 14 local materials used was Abelmoschus esculentus and has no negative effect on the ${ }^{\circ}$ API of the Crude Oil.

The individual best performing local material gave better maximum oil displacement efficiency when used singly than when used as a blend. These local materials gave additional oil recovery of $17.3 \%, 5.2 \%$ and $18.7 \%$ for potash, Carica papaya leaves extract and Abelmoschus esculentus respectively.

The local material ASP blend did not perform well when compared to the synergy in conventional ASP flooding as reported in literature. Which could be attributed to the Crude oil properties or chemical reaction between the local material blends.

Parameters responsible for a successful Chemical flooding EOR are TAN and pH for alkaline flooding; CMC and formation of Winsor Type 111 phase behaviour for Surfactant flooding; and avoidance of phase separation and aggregate size for polymer flooding.

Most of the local materials used were good but some were better than others. The selection criterion was based on cost effectiveness, value and availability. These local materials when modified and refined can compete with synthetic chemicals in the global market.

\section{REFERENCES}

[1] Abhijit S., Achinta B., Keka O. and Ajay M. (2012): "Comparative Studies on Enhanced Oil Recovery by Alkali-Surfactant and Polymer Flooding". J. Petrol Explor Prod. Technol, 2, pp. 67-74

[2] Abubakar H., Zulkefti B. and Abdurahman H. (2015): “An overview of oil production stages: Enhanced Oil Recovery Techniques and Nitrogen Injection". International Journal of Environmental Science and Development. 6 (9), pp. 693-701

[3] Adebayo, T., Ayotunde C. and Precious C. (2012): "Sawdust as a Filtration Control and Density Additives in Water-Based Drilling Mud". International Journal of Scientific and Engineering Research, 3 (7)

[4] Adetuyi, A., Osagie, U. and Adekunle, A. (2011): "Nutrient, antinutrient, mineral and zinc bioavailability of okro (Abelmoschus esculentus (L) Moench variety)". pp. 1.2.49.54

[5] Bankole J. K., Ngokere A. A., Ajibade O. M., Igunbor C. M. and Eloka C.C. (2015): "Degenerating effects of Potash (Kaun $\left.-\mathrm{K}_{2} \mathrm{CO}_{3}\right)$ on the Kidney: Unabated Continental Challenge to human health in Nigeria, Annals of Biological Research, 6 (3), pp. 12-17

[6] Bryan J. and Kantzas A. (2009): "Improvements in Heavy Oil Recovery". Journal of Physic.Conference series. 147: 012058

[7] Chaieb, I. (2010): Saponins as insecticides: a review. Tunisian Journal of Plant Protections. 5(1), pp. 39-50

[8] Chiwetelu C. I., Neale G. H., Hornof V. and George A. E. (1994) "Recovery of a Saskatchewan Heavy Oil using Alkaline solution", Journal of Canadian Petroleum Technology, 33 (4), pp. 37-42

[9] Ding B., Zhang G., Ge J. and Liu X. (2010): "Research on Mechanisms of Alkaline Flooding for Heavy Oil”. Energy and Fuels. 24(12), pp. 6346-6352

[10] ENORDET (2013): "Surfactants for Enhanced Oil Recovery (Shell Chemicals)". Revitalize your mature fields with ENORDET Surfactants.

[11] Fatoke O. A. (2010): "Sequence Stratigraphy of the Pliocene-Pleistocene Strata and shelf-margin deltas of the eastern, Niger Delta, Nigeria (Ph.D). University of Houston

[12] Gail (2013): Maryland Department of Health and Mental Hygiene (DHMH)

[13] George J., Clarence A. and Gary A. (2015): "Surfactant Based Enhanced Oil Recovery and Foam Mobility Control”. Semi Annual Technical Report. pp. 1-156

[14] Hongyan W. and Brian M. (2013): "Development of a new surfactant-polymer system and its implementation in Dangang Oilfield". Journal of Petroleum and Gas Engineering. 4 (5), pp. 118-126

[15] Igwengi, I.O. and Akubugwo, E.I. (2010): “Analysis of four seeds used as soup thickeners in the South Eastern part of Nigeria". Chemistry and Chemical Engineering (ICCLE), IEEE,

[16] pp. 426-430.

[17] Igwenye, I.O. and Azoro, B. N. (2014): "Proximate and Phytochemical Compositions of four Indigenous seeds used as soup thickeners in Ebonyi State, Nigeria". IOSR Journal of Environmental Science, Toxicology and Food Technology, 8 (6), pp. 35-40

[18] Ikechukwu O. and Emmanuel I. (2010): "Analysis of four seeds used as soup thickeners in the South Eastern part of Nigeria”. 2010 International Conference on Chemistry and Chemical Engineering.

[19] Industrial Chemicals Division "Silicates in Enhanced Oil Recovery". PQ Corporation, Bulletin 35-04, pp. 1-4

[20] James J. Sheng (2015): "Status of Surfactant EOR Technology". KeAi Advancing Research Evolving Science Petroleum (1), pp. 97-105 
[21] Laura R. (2011): “Advances in Enhanced Oil Recovery Processes". University of New Brunswick, Chemical Engineering Department, Canada. pp. 1-43

[22] Lei-Ting S., Cheng L., Shan-Shan Z., Jie X., Bao-Zong S. and Zhong-Bin Y. (2013): "Study on Properties of Branched Hydrophobically Modified Polyacrylamide for Polymer Flooding". Journal of Chemistry. 2013, Article ID 675826, p. 5

[23] Mandal A. (2015): "Chemical flood enhanced oil recovery": A review. Int. J. Oil, Gas and Coal Technology, 9 (3), pp. 241-264

[24] Mee C. (2015): "Nutritional, Antinutritional and Phytochemical Status of Okra leaves (Abelmoschus esculentus)". African Journal of Biotechnology. 14 (8), pp. 683-687

[25] Mohammad A. A., Morteza G. and Seyed R. S. (2014): "Wettability Alteration in Carbonate Rocks by Implementing New Derived Natural Surfactant: Enhanced Oil Recovery Applications". Transport in Porous Media, 106(3), pp. 645-667

[26] Mohammad A. A., Seyed R. S. (2018): "Spotlight on the New Natural Surfactant Flooding in Carbonate Rock Samples in Low Salinity Condition”. Scientific Report, 8(1), p. 10985

[27] Mojdeh D. (2015): "Chemical Enhanced Recovery". 2015 Society of Petroleum Engineers Annual Technical Conference and Exhibition, Houston.

[28] Nmegbu, C.G. (2014): "Pore Characterization of Niger-Delta Sandstone formations by Numerical methods". International Journal of Emerging Technology and Advanced Engineering. 4 (5), pp. 488-493

[29] Nwosu, J.N. (2012): "The Rheological and Proximate Properties of some food thickeners (Ukpo, Achi, Ofor) as affected by processing". International Journal of Basic and Applied Sciences. 1(4), pp. 304-312

[30] Ogbeide I., Mamudu A. and Olafuyi O. (2015): Viscosity evaluation and oil recovery performance of ASP slug. Improved Oil Research Group, University of Benin.Oilflow Conference Proceedings. pp. 221-235

[31] Ogolo N., Ogiriki S., Onyiri V., Nwosu T. and Onyekonwu M. (2015): Performance of foreign and local agents for Enhanced Oil Recovery of Nigeria Crude. SPE 178305.

[32] Ojo O. V., Onyekonwu, M.O., Ogolo, N.A. and Ubani, C. (2013): Effect of viscosity of Alkaline/Surfactant/Polymer on Enhanced Oil Recovery in Heterogeneous Sands. SPE 167550. pp. 3-11.

[33] Onudibia, M. E., Dim L.A. and Ogunleye, P.O. (2014): Elemental analysis of common food thickeners. Nigerian Journal of Physics, 25(2), pp. 144-149

[34] Onukun, O. (2012): Evaluation of aqueous-extracts of five plants in the control of flea beetles on okra (Abelmaschus esculentus (L.) B Moench). Efficacy of plant extracts against flea beetles. JBiopest, 5 (supplementary). pp. 62-67

[35] Onyegbado, C. O., Iyagba, E. T. and Offor, O. J. (2002): Solid Soap Production using Plantain Peel Ash as Source of Alkali. Journal of Applied Sciences and Environmental Management, 6 (1), pp. 73-77.

[36] Paweena D., Suppasil M., Hatairat M., and Aran H. (2010): Emulsifier Properties of the Manno-protein extract from yeast isolated from sugar palm wine. Science Asia, 36, pp. 312-318

[37] Qingyi X., Mitsutoshi N., Zengshe L., and Takeo S. (2011): Soybean-Applications and Technology, pp. 20

[38] Shunhua L. (2008): Alkaline Surfactant Polymer Enhanced Oil Recovery Process. ChemFlood Thesis, Rice University. pp. 74-180

[39] Shunhua L., Robert F., Clarence A. and George J. (2010): Alkaline Surfactant Polymer processes: Wide range of conditions for good recovery. SPE Journal, SPE 113936 ,

[40] pp. 282-293

[41] Thomas, S.C.(2008): "Book-Vegetable and Fruits: Nutritional and Therapeutic values". CRC Press. p. 76

[42] Wan Z., Wan B. and Arina S. (2014): The Effect of Ash from Oil Palm Empty Fruit Bunch to Cement Properties. Engineers Australia. pp. 1628

[43] Zhiwei W., Xiang'an Y., Tao C., Jie Y., Heng Y., (2014): Effect of viscosity and Interfacial Tension of Surfactant-Polymer flooding on oil recovery in high temperature and high salinity reservoirs. Journal of Petroleum Exploration and Production Technology.6(1), pp. 9-16

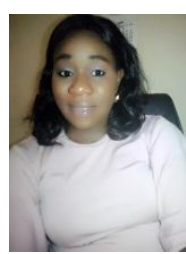

Dr. Chidinma U. Uzoho(Bachelor of Science in Chemical Engineering, Master of Science in Petroleum \& Gas Engineering, and Doctor of Philosophy in Petroleum Engineering; all from the University of Port Harcourt, Nigeria). She is a Consultant; majorly in Process Utilities and Enhanced Oil Recovery. A Post-Ph.D ResearchFellow.Member Society of Petroleum Engineering, Chaplain of World Mission Chapel, and Director of Literature, Sickle Magazine. Dr. ChidinmaUzoho has proven through research that local chemicals can be as effective as synthetic chemicals when refined and modified.

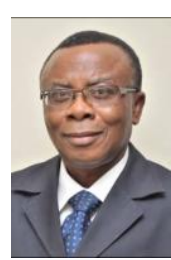

Professor Mike O. Onyekonwu (Bachelor of Science first class, University of Ibadan, Nigeria, Master of Science in Petroleum Engineering, Stanford (California), Doctor of Philosophy, Stanford (California). He is the Managing Consultant, Laser Engineering and Resources Consultants. A Professor in University of Port Harcourt Rivers State, Nigeria; Department of Petroleum and Gas Engineering. Member Rural Electrification Board, Lilu, Nigeria. Member Society of Petroleum Engineers, Nigeria Society of Engineering and Full Gospel Business Men's Fellowship International. Professor Mike Obi Onyekonwu has been listed as a noteworthy Petroleum Engineer educator by Marquis.

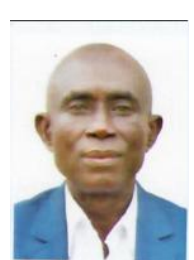

Professor Onyewuchi Akaranta(Bachelor of Science in Chemistry, University of Nigeria, Master of Science in Polymer Science \& Technology and Doctor of Philosophy inSurface Coatings). He is a Professor in University of Port Harcourt, Rivers State, Nigeria; Department of Chemistry. Member of Oil and Colour Chemist Association, Chemist Society Nigeria and Polymer Institute Nigeria. Professor Onyewuchi Akaranta has been listed as a noteworthy Chemist educator by Marquis.

\section{ABBREVIATIONS AND ACRONYMS}

$\begin{array}{lll}\mathrm{UEg} & = & \text { Unpurified Elaeis guineensis As } \\ \mathrm{PEg} & = & \text { Purified Elaeis guineensis Ash }\end{array}$

$\mathrm{Ki}=$ Khayaivorensis Ash

$\mathrm{Ms}=$ Musa sapientum Ash

$\mathrm{C} \mathrm{p}=$ Carica papaya leaves

$\mathrm{C} \mathrm{n}=$ Cocosnucifera

$\mathrm{Va}=$ Vernoniaamygdalina

$\mathrm{B}$ e $=$ Brachystegiaeurycoma

$\mathrm{Dm}=$ Detariummicrocarpum

$\mathrm{Mf}=$ Mucunaflagellipes

$\mathrm{I} \mathrm{g}=$ Irvingiagabonensis

$\mathrm{Ae}=$ Abelmoschus esculentus

$\mathrm{EOR}=$ Enhanced Oil Recovery

$\mathrm{PV}=$ Pore volume

$\mathrm{E}_{\mathrm{D}}=$ Displacement Efficiency

TAN $=$ Total Acid Number

$\mathrm{IFT}=$ Interfacial Tension

$\mathrm{NaCl}=$ Sodium chloride

$\mathrm{AS}=$ Alkaline- Surfactant

$\mathrm{AP}=$ Alkaline- Polymer

$\mathrm{SP}=$ Surfactant- Polymer

$\mathrm{ASP}=$ Alkaline-Surfactant-Polymer

$\mathrm{CMC}=$ Critical Micelles Concentration

$\mathrm{MCCF}=$ Mobility Controlled Caustic Flood

$\mathrm{PG}=$ Pressure Gauge

$\mathrm{MC}=$ Measuring Cylinder

$\mathrm{V}_{\mathrm{oi}}=$ Volume of oil initially in-place

$\mathrm{V}_{\mathrm{wc}}=$ Volume of connate water

$\mathrm{S}_{\mathrm{wc}}=$ Connate water saturation

$\mathrm{S}_{\mathrm{oi}}=$ Initial oil saturation

$\mathrm{MR}=$ Mobility Ratio

API = American Petroleum Institute

ROIP = Residual Oil-In Place

Rec. $=$ Recovery

OOIP = Oil Initially-In Place

$\mathrm{DE}=$ Displacement Efficiency

$\boldsymbol{\phi}=$ Porosity

$\mathrm{IOR}=$ Improved Oil Recovery

$\mathrm{PCA}=$ Blend of Potash $/ \mathrm{C} \mathrm{p} / \mathrm{A}$ e

$\mathrm{S}$. cerevisiae KAOI = Sample Name 